\title{
PHENOLIC ACID PROFILING BY RP-HPLC: EVALUATION OF ANTIBACTERIAL AND ANTICANCER ACTIVITIES OF CONOCARPUS ERECTUS PLANT EXTRACTS
}

\author{
*KHALIL R, ALI Q, HAFEEZ MM, MALIK A \\ Institute of Molecular Biology and Biotechnology, University of Lahore, Lahore, Pakistan \\ Corresponding author email: ahadbukhari16@gmail.com \\ (Received, $9^{\text {th }}$ February 2020, Accepted $12^{\text {th }}$ May 2020)
}

\begin{abstract}
Due to the versatile application of plants the utilization of plants and their inferred substances builds up day by day for the revelation of new curative agents. Conocarpus erectus has placed in the family Combretaceae, in one of the two species of Conocarpus genus and ordinarily exists in tropical and subtropical regions of the world. In some countries it is used as folk medicine for fever, anemia, diabetes, catarrh, diarrhea and conjunctivitis. The current study was carried out to investigate the antibacterial and anticancer properties of the plant. The four defatted methanol extracts of $C$. erectus different parts (leaves, stems, fruits and bark) showed high antibacterial and anticancer activity even with small quantity of dose. Antimicrobial assay was used to check out the antibacterial activity against 6 bacterial strains Escherichia coli, Staphylococcus Aureus and Klebstella Pneumoniae. The results show that gram positive bacteria show more sensitivity and zone of inhibition as compared to gram negative bacteria. For anticancer activity, MTT assay was performed on HepG2 cells for this purpose. Plant extorts show anticancer activity with a minute quantity. For phytochemical screening defatted methanol extract of Conocarpus erectus was subjected to the silica gel glass column go behind by (RP-HPLC-UV-ESI-MS). It contains phenol such as tannin and flavinoid as major component. Plant contain Ellagic acid; di-hexahydroxy diphenyl, Vascalgin isomer as foremost tannin component. Gallic Acid, Kaempferol on the base of mass spectra and time of retention. The extract of Conocarpus erectus (leaves, shoot, bark \& fruit) parts shows high antibacterial, antioxidant and heptaprotective activities due to phenolic content. Tannin has high antibacterial activity than other compound. C.erectus is notable for its folkloristic curative potential. More in vivo and in vitro phytochemical studies are needed to use the plant for prevention and treatment of many diseases.
\end{abstract}

Keywords: Conocarpus erectus, HPLC, Ellagic Acid, Gallic Acid, Antibacterial, Anticancer, phytochemicals unpredictability, which thusly requires wide

\section{Introduction}

To expand the quality of wellbeing around the world the utilization of distinctive products medication has risen up out of conventional to present day treatment. The advancement of sciences and innovations has profoundly upheld the assessment on characteristic products medications in all angles (Cragg et al., 2012; Kinghorn et al., 2011). In any case, since regular products based medication disclosure is related with some inherent challenges, pharmaceutical industry has moved its primary concentration toward engineered compound libraries and HTS for disclosure of new medication leads (Beutler, 2009; David et al., 2015). The acquired outcomes, be that as it may, did not meet up the desires as obvious in a dilapidated number of new drugs achieving the market (David et al., 2015; Kinghorn et al., 2011). This situation rejuvenated the enthusiasm for characteristic products based medication disclosure, in spite of its high interdisciplinary investigation approaches (Heinrich, 2010). The foremost-composed records on therapeutic utilizations of plants date back to 2600 $\mathrm{BC}$ including around 1000 plant resolute meds and report the presence of a complex restorative framework in Mesopotamia (Borchardt, 2002; Cragg and Newman, 2013). Conocarpus erectus has placed in the family Combretaceae, in one of the two species of conocarpus genus and ordinarily exists in tropical and subtropical districts of world, (Ayoub, 2010; Jagessar and Cox, 2010). C. erectus is an evergreen tree with $20 \mathrm{~cm}$ in diameter and $6 \mathrm{~m}$ tall with scattering crown, which is a typical constituent of mangal in beach front region of tropical America (Bailey, 1976; West, 1977). The family Combretaceae has a place with the order myrtales and consists of 500 species and 20 genera. $C$. erectus is commonly known as Botocillo (Spanish), Mangle botoncillo, Button mangrove, Buttonbush, Yana, Mangle boton, Mangle Negro, Witte mangle, Mangle prieto. Conocarpus

[Citation: Khalil, R., Ali, Q., Hafeez, M.M., Malik, A. (2020). Phenolic acid profiling by RP-HPLC: evaluation of antibacterial and anticancer activities of Conocarpus erectus plant extracts. Biol. Clin. Sci. Res. J., 2020: 10 doi: https://doi.org/10.54112/bcsrj.v2020i1.10]. 
erectus is also known as button wood or button mangrove (Bashir et al., 2015). C. erectus L. (Combretaceae), significantly known as mangrove button (Nascimento et al., 2016). In South America, is available since Ecuador until Brazil (von Linsingen et al., 2009). This Plant is a fundamental resource of natural product, other than curative agents. In addition, they additionally can be a potential source for a variety of synthetic constituents which are naturally active (Martins et al., 2015). C. erectus is broadly developed as decorative tree around the world (Shohayeb et al., 2013) and its wood is utilized for fence posts, crossties, turnery, vessel building, kindling and landscaping purposes (Carneiro et al., 2010). In society prescription, this plant is utilized against irondeficiency, catarrh, conjunctivitis, gonorrhea, diabetes, prickly heat, fever, migraine, dying, tumors, orchitis, diarrhea, syphilis and swelling, (AbdelHameed et al., 2012; Ayoub, 2010; Shohayeb et al., 2013). The leaves are eaten, and their decoction is inebriated for fever. The bark and the product of this species are utilized as inoculate in the treatment of the wounds, diabetes, Haemorrhoids and Diarrhea (Raza et al., 2016). A portion of the proven natural properties of $C$. erectus are hepatoprotective (AbdelHameed et al., 2013), antioxidant (Abdel-Hameed et al., 2014), anticancer (Abdel-Hameed et al., 2012) and also antimicrobial (Shohayeb et al., 2013) exercises. Likewise, it was proposed that ethanolic, n-hexane, chloroform and n-butanolic separates of the plant could be an intense source of curative agents in anticipating or abating the way toward aging and the oxidative anxieties related to degenerative diseases(Raza et al., 2016). C. erectus is notable for its folkloristic curative potential including treatment of diabetes(Nascimento et al., 2016).Some logical confirmations are likewise exhibiting in help of its curative movements (Abdel-Hameed et al., 2013; Abdel-Hameed et al., 2012). The objective of this research was conducted to contribute to the better knowledge about Conocarpus erectus plant as antibacterial, anticancer potential and phenolic content from solvent extraction of plant parts (shoot, root, bark and leaves) that ultimately provide a novel source for bioactive compound for use against human disease. The assessment of phenolic acid profiling was carried out by RP-HPLC from testing solvent fractions of Conocarpus erectus.

\section{Material and methods}

\section{Plant Material}

Conocarpus erectus plant was collected from Lahore, Punjab, Pakistan and plant sample was identified by Dr. Quban ali Professor, IMBB, UOL. Washed with tap water for purpose to remove unwanted material and rinsed with distilled water. Cleaned and dried plant material will be blended with the help of blender and distilled water. 50 gram of blended Conocarpus erectus parts (leaves, shoot, bark and fruit) will be extracted by using $120 \mathrm{ml}$ of $99.9 \%$ ethanol and $20 \mathrm{ml}$ distilled water in $250 \mathrm{ml}$ flasks (Figure 1). Whole experiment work was done at the chemical biology and microbiology research laboratory at the institute of Molecular Biology and Biotechnology (IMBB) and plants Biotechnology Laboratory of Centre of research in Molecular Medicine (CRIMM), The University of Lahore, Lahore.

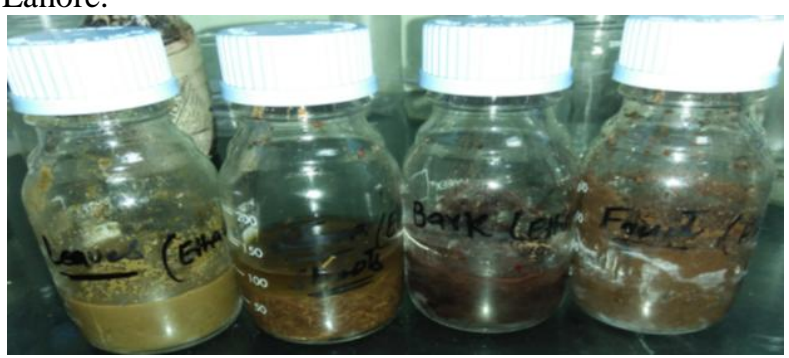

Figure 1. Ground plant materials for different fractions

\section{Antimicrobial potential}

Test microorganisms

Escherichia coli, Staphylococcus Aureus and Klebstella Pneumoniae were collected from the Microbiology research Laboratory of Institute of Molecular Biology and Biotechnology (IMBB), The University of Lahore, Lahore.

\section{Preparation of culture media:}

For bacteria NA (Nutrient Agar) were used as growth medium and $6.72 \mathrm{~g}$ nutrient agar in $240 \mathrm{ml}$ distilled water for bacteria was dissolved in deionized water and mixed thoroughly by gentle shaking and sterilized at $121^{\circ} \mathrm{C}$ for 15 minutes at $15 \mathrm{lbs}$ pressure in autoclave (Hiryama manufacturing corporation, japan). Sterilized agar media was then run in plastic petri plates and left for antimicrobial assay.

\section{Antimicrobial susceptibility Assay}

Different fractions of Conocarpus erectus shoots were evaluated for their microbial activities by using different assay. Bacteria liquid cultures were inoculated onto the agar plates by the help of sterilized cotton swab. Sterilized cotton swabs were used for inoculation of bacteria liquid culture onto agar plates. Petri plates having $20 \mathrm{ml}$ of Nutrient agar (NA) and allowed to solidify. Sterile discs $(10 \mathrm{~mm})$ were placed on the surface of medium in Petri plates aseptically and pressed a little to ensure from contact in sterilized laminar air flow cabinet (Labconco). A volume of 2.5ul, 5ul and 10ul of different fractions was loaded on discs and incubated at $37^{\circ} \mathrm{C}$ for $24 \&$ 48 hours in incubator. The experiment was performed in triplicate. The antimicrobial activity of each fraction was recorded based in the zone of inhibition of bacterial growth by the fractions after 24 hours and 48 hours at the end of incubation period. All results

[Citation: Khalil, R., Ali, Q., Hafeez, M.M., Malik, A. (2020). Phenolic acid profiling by RP-HPLC: evaluation of antibacterial and anticancer activities of Conocarpus erectus plant extracts. Biol. Clin. Sci. Res. J., 2020: 10 doi: https://doi.org/10.54112/bcsrj.v2020i1.10]. 
were recorded in the form of zone of inhibition with diameter in $\mathrm{cm}$ and recorded on graph.

Cell Culture and MTT assay (Ant proliferative assay)

\section{Dose Preparation}

Three different dose concentrations were made. This gives us 3 different doses for testing purpose on cell lines to find the minimum amount of dose which can show the anti-cancer activity. Three doses of $25 \mu 1,50$ $\mu \mathrm{l}$, and $75 \mu \mathrm{l}$ each stored in eppendorf and stored in a freezer

\section{Cell Line plating}

A 96 well culture plate was used to grow the HepG2 cell lines to check the anti-cancer activity of Conocarpus erectus obtained which were obtained silica gel column chromatography. Cells were plated on a 96 well plate from a fresh culture and stored in a $\mathrm{Co} 2$ pressurized $37^{\circ} \mathrm{C}$ incubator for attachment to surface. 36 wells were required for 3 doses three times each for average count.

\section{MTT assay}

MTT (3-(4,5- Dimthylthiazol-2-yl)-2, 5diphenyltetrazolium bromide) assay was performed on HepG2 cancer cell lines and tissue culture was set at $5 \% \mathrm{CO} 2,37^{\circ} \mathrm{C}$ temperature, $7.4 \mathrm{pH}$ and $90 \%$ humidity. Growth medium was prepared with DMEM, 10\% FBS, and 100 units of antibiotics and $2 \mathrm{mM}$ glutamine. The cells were cultured in the medium and incubated in the conditions set (Figure 2 ). The cell growth was maintained in the log phase. After the required growth of cells the MTT assay was performed. The MTT solution was prepared with $2.5 \mathrm{mg} / \mathrm{m}$ MTT and extraction buffer. Extraction buffer was prepared using 20\% SDS and 50\% DMSO and distilled water. The cells were counted using the Haemocytometer. 5000cells/well in $0.2 \mathrm{ml}$ of DMEM medium were taken Few hours after the plating of cell to 96 well plate, doses were prepared for MTT assay and applied to the wells. Now $25 \mu \mathrm{L}, 50 \mathrm{ul}$ and $75 \mathrm{ul}$ of dose were added to three wells each. After the application of doses Plate was placed in the incubator for 48 hours at $37^{\circ} \mathrm{C}$. After 48 hours, MTT reagent was added in each of the well in a concentration of 25 $\mu \mathrm{L}$ each. Another incubation of 3 hours was given. Then the supernatant was removed and DMSO was added in each well in a concentration of $100 \mu \mathrm{L}$ each.

\section{ELISA reading}

ELISA reader was used to get the absorption values at $570 \mathrm{~nm}$ after 1 hour of the addition of DMSO in each well and again after overnight to find any differences. The readings were measured in terms of $\%$ cell viability. The percentage relative cell viability was calculated using the following equation:

$\%$ relative cell viability $=\frac{\mathrm{A} 570 \text { of sample }}{\mathrm{A} 570 \text { of control }} \times 100$
Where, A570 is the absorbance of sample and blank at $570 \mathrm{~nm}$. The readings were measured in terms of $\%$ cell viability.

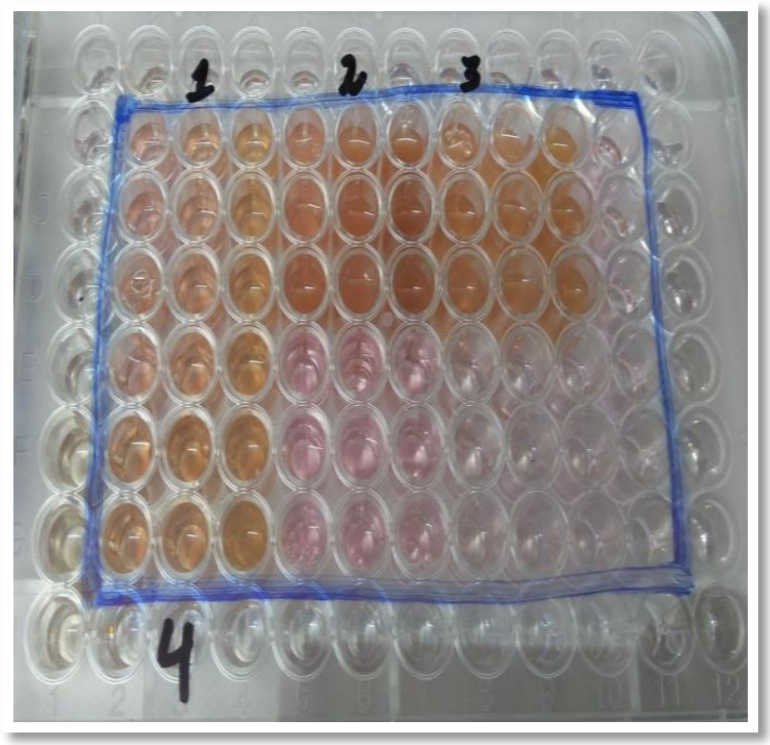

Figure 2.96 well plate with different doses

Phytochemical Analysis

Four different fractions of defatted ethanol extract from Conocarpus erectus parts (leaves, fruit, stem and fruit) were selected for the phytochemical analysis for the investigation of natural products such as tannin, flavonoids, saponnin, carbohydrate and alkaloids.

\section{Sample preparation}

Phenolic compounds were identified and quantified in the Conocarpus erectus fractions that were determined by HPLC method described by(Park and Jhon, 2010). 10ml of each basic extract were dissolved in $10 \mathrm{ml} \mathrm{Hplc}$ grade methanol with $8 \mathrm{ml}$ of distilled water. The resultant solution was incubated at $90^{\circ} \mathrm{C}$ for $2 \mathrm{~h}$ and filtered with $0.2 \mathrm{~mm}$ Millipore membrane filter before injection into HPLC.

High performance liquid chromatography

The HPLC separation was performed using HPLC system with column 20RBAX ECLIPSE, XDB-C18, $(5 \mu \mathrm{m} ; 4.6 \times 150 \mathrm{~mm}$, Agilent USA), UV-VIS Spectra-Focus detector and injector-auto sampler. The isocratic mobile phase, consisting of (tetra hydro-furan/aceto-nitrile/ $0.05 \%$ phosphoric acid solution (20:3:77, v/v/v) A was delivered at a flowrate of $1 \mathrm{~mL} / \mathrm{min}$ with some amendments in time for 1 minute and wavelength (Figure 3). Prior to use the mobile phase was filtered through $0.2 \mathrm{~mm}$ Millipore membrane filters and degassed by sonication in an ultra-sonic bath. Detection wavelength was set at 280 $\mathrm{nm}$ and the column temperature was maintained at room temperature $\left(37^{\circ} \mathrm{C}\right)$ with injection volume of $10 \mu \mathrm{L}$. 


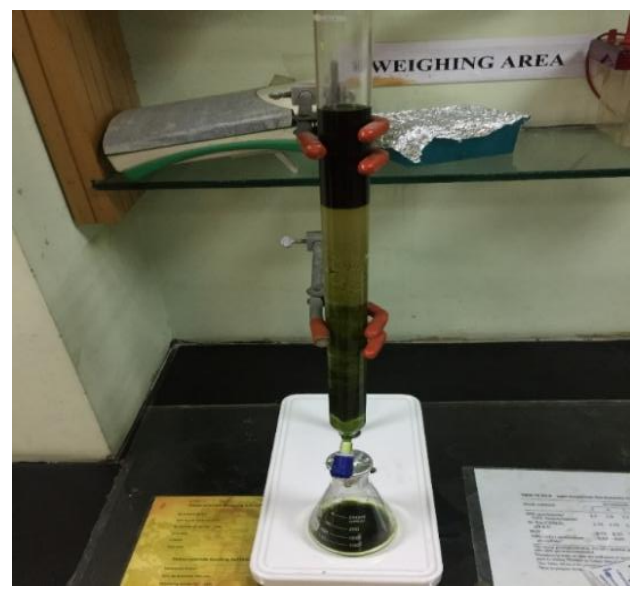

Figure 3. Running Column Chromatography

\section{Results}

\section{Antibacterial activity of shoot}

The result shows dose dependent antibacterial activity of ethanol fraction prepared from the shoots of Conocarpus erectus, bacterial strains Escherichia coli, Staphylococcus aureus and Klebsiella pneumoniaee. Ethanolic fraction at dose of 5ul, 10ul and $15 \mathrm{ul}$ against tested bacterial strains showed zone of inhibition. Ethanolic fraction at dose of 5ul, 10ul and $15 \mathrm{ul}$ against $E$. coli showed zone of inhibition after $24 \mathrm{hrs}$ with diameter of $4.08,5.02$ and $5.02 \mathrm{~cm}$, and after 48hrs 3.76, 4.71and 4.91 in diameter respectively. Similarly, the activity of Ethanolic fraction at dose of $5 \mathrm{ul}, 10 \mathrm{ul}$ and $15 \mathrm{ul}$ against Staphylococcus aureus showed zone of inhibition after $24 \mathrm{hrs}$ with diameter of $3.90,4.9$ and $4.90 \mathrm{~cm}$ and after $48 \mathrm{hrs} 3.86,4.51$ and 4.71 in diameters respectively. Klebsiella pneumoniaee which was also found susceptible and showed diameter of $3.9 \mathrm{~cm}, 4.8$ and 4.9 after 24 hrs and 3.5, 4.5 and 4.3 after 48 hrs. The results show that in ethanolic extract of shoots of C. erectus maximum antibacterial activity was found against $E$. coli. The dose of 10ul show more activity than other doses (Table 1)

Table 1: Bacterial zone of inhibition under the application of shoot extract

\begin{tabular}{lllllll}
\hline Shoot sample & $\boldsymbol{E}$. coli & & S. aureus & \multicolumn{3}{c}{ K. pneumoniae } \\
\hline Doses & 24hrs & 48hrs & 24hrs & 48hrs & 24hrs & 48hrs \\
2.5ul & 4.08 & 3.76 & 3.9 & 3.8 & 3.9 & 3.5 \\
5ul & 5.02 & 4.71 & 4.9 & 4.5 & 4.8 & 4.3 \\
10ul & 5.02 & 4.91 & 4.9 & 4.7 & 4.9 & 4.5 \\
\hline
\end{tabular}

Antibacterial activity of Bark

The ethanolic fraction at dose of 2.5ul, 5ul and 10ul against Staphylococcus aureus showed zone of inhibition after $24 \mathrm{hrs}$ with diameter of $4.97,5.72$ and 6.65 and after $48 \mathrm{hrs} 5.38,6.01$ and 7.51 in diameters respectively. In the same way, the activity of Ethanolic fraction at dose of 2.5ul, 5ul and 10ul against Escherichia coli showed zone of inhibition after $24 \mathrm{hrs}$ with diameter of $3.1,4.8$ and $5.7 \mathrm{~cm}$ and after 48hrs 4.9, 5.3 and 6.1 in diameters respectively. Klebsiella pneumoniae which was also found susceptible and showed diameter of $3.3 \mathrm{~cm}, 4.4$ and 4.9 after $24 \mathrm{hrs}$ and 3.8, 4.9 and 5.3 after $48 \mathrm{hrs}$. The outcomes demonstrate that Gram-positive bacteria Staphylococcus aureus is more sensitive than Gramnegative bacteria Escherichia coli and Klebsiella pneumoniaee at dose of $2.5 \mathrm{ul}, 5 \mathrm{ul}$ and 10ul. 10ul show more activity than other doses (Table 2).

Table 2: Bacterial zone of inhibition under application of bark extract

\begin{tabular}{lcccccc}
\hline Bark sample & E. coli & & S. aureus & \multicolumn{3}{c}{ K. pneumoniae } \\
\hline Doses & 24hrs & 48hrs & 24hrs & 48h & 24hrs & $\mathbf{4 8}$ \\
& & & & rs & & hrs \\
2.5ul & 4.97 & 5.38 & 3.1 & 4.9 & 3.3 & 3.8 \\
5ul & 5.72 & 6.01 & 4.8 & 5.3 & 4.4 & 4.9 \\
10ul & 6.65 & 7.51 & 5.7 & 6.1 & 4.9 & 5.3 \\
\hline
\end{tabular}

\section{Antibacterial activity of Fruit}

Ethanolic fraction at dose of 2.5ul, 5ul and 10ul against Staphylococcus aureus showed zone of inhibition after $24 \mathrm{hrs}$ with diameter of $3.7,4.2$ and 5.4 and after $48 \mathrm{hrs} 4.6,5.3$ and 6.28 in diameters respectively. In the same way, the activity of Ethanolic fraction at dose of 2.5ul, 5ul and 10ul against Escherichia coli showed zone of inhibition after $24 \mathrm{hrs}$ with diameter of $3.5,3.8$ and $4.9 \mathrm{~cm}$ and after $48 \mathrm{hrs} 3.9,4.9$ and 5.3 in diameters respectively.
Klebsiella pneumoniaee which was also found susceptible and showed diameter of $3.7 \mathrm{~cm}, 4.3$ and 5.0 after $24 \mathrm{hrs}$ and 3.9, 4.6 and 5.3 after $48 \mathrm{hrs}$. The domino effects explain that Klebsiella pneumoniae show least activity under the application of fruit extorts. Escherichia coli show moderate effects and Staphylococcus aureus illustrate more activity. Bacterial zone of inhibition at 10ul dose was more against Staphylococcus aureus (Table 3).

Table 3. Bacterial zone of inhibition under application of Fruit extract

\begin{tabular}{lccllll}
\hline Fruit sample & E. coli & & S. aureus & \multicolumn{2}{l}{ K. pneumoniae } & \\
\hline Doses & $24 \mathrm{hrs}$ & $48 \mathrm{hrs}$ & $24 \mathrm{hrs}$ & $48 \mathrm{hrs}$ & $24 \mathrm{hrs}$ & $48 \mathrm{hrs}$ \\
\hline
\end{tabular}

[Citation: Khalil, R., Ali, Q., Hafeez, M.M., Malik, A. (2020). Phenolic acid profiling by RP-HPLC: evaluation of antibacterial and anticancer activities of Conocarpus erectus plant extracts. Biol. Clin. Sci. Res. J., 2020: 10 doi: https://doi.org/10.54112/bcsrj.v2020i1.10]. 


\begin{tabular}{lcccccc}
\hline $2.5 \mathrm{ul}$ & 3.7 & 4.6 & 3.5 & 3.9 & 3.7 & 3.9 \\
5ul & 4.2 & 5.3 & 3.8 & 4.9 & 4.3 & 4.6 \\
10ul & 5.4 & 6.28 & 4.9 & 5.3 & 5.01 & 5.3 \\
\hline
\end{tabular}

Antibacterial activity of Conocarpus erectus

Leaves

Ethanolic fraction at dose of 2.5ul, 5ul and 10ul against Staphylococcus aureus showed zone of inhibition after $24 \mathrm{hrs}$ with diameter of $4.27,4.56$ and 4.8 and after 48hrs 4.6, 5.3 and 5.9 in diameters respectively. In the same way, the activity of Ethanolic fraction at dose of 2.5ul, 5ul and 10ul against Escherichia coli showed zone of inhibition after $24 \mathrm{hrs}$ with diameter of $3.6,3.9$ and $4.1 \mathrm{~cm}$ and after $48 \mathrm{hrs} 3.9,4.1$ and 5.3 in diameters respectively. Klebsiella pneumoniae which was also found susceptible and showed diameter of 3.6, 4.1 and 4.8 after $24 \mathrm{hrs}$ and 4.1, 5.2 and 5.9 after $48 \mathrm{hrs}$. The domino effect shows that Escherichia coli are more sensitive than other bacterial strains (Table 4).

Table 4: Bacterial zone of inhibition under the application of leaves extract

\begin{tabular}{lcccccc}
\hline Fruit sample & $\boldsymbol{E}$. coli & \multicolumn{3}{c}{ S. aureus } & \multicolumn{3}{c}{ K. pneumoniae } \\
\hline Doses & 24hrs & $\mathbf{4 8 h r s}$ & $\mathbf{2 4 h r s}$ & $\mathbf{4 8 h r s}$ & $\mathbf{2 4 h r s}$ & 48hrs \\
2.5ul & 4.27 & 4.5 & 3.5 & 3.9 & 3.6 & 4.1 \\
5ul & 4.56 & 5.3 & 3.9 & 4.1 & 4.1 & 5.2 \\
10ul & 4.8 & 5.9 & 4.1 & 5.3 & 4.8 & 5.5 \\
\hline
\end{tabular}

Anticancer activity of Ethanolic fraction of Conocarpus erectus parts on HepG2 cell line

In order to find out anticancer activity of different fractions of Conocarpus erectus plant parts against HepG2 cell line MTT assay was performed. A range of different doses $(25 \mu \mathrm{l}, 50 \mu \mathrm{l}$ and $75 \mu \mathrm{l})$ of Conocarpus erectus was used.

Negative Control

One negative control was set during MTT assay for the final average calculation along with treatment.
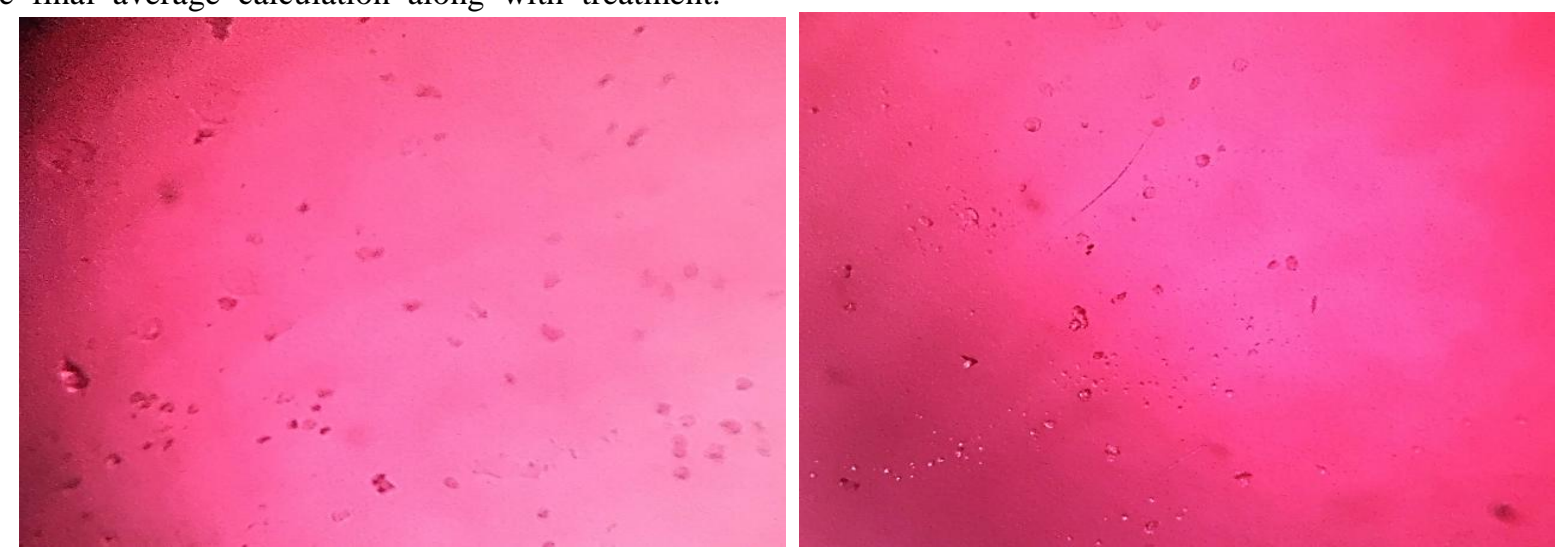

Figure 4. Negative control (left) Positive control after treatment (right)

Anticancer activity of shoot extract on HepG2 cell line

In order to find out anticancer activity of different fractions of $C$. erectus against HepG2 cell line MTT assay was performed. A range of doses prepared by ethanol of three different fractions $(25 \mathrm{ul}, 50 \mathrm{ul}$ and $75 \mathrm{ul})$ of $C$. erectus was used. Potent anticancer activity was resulted by sample 1 of ethanolic fractions of $C$. erectus observed (Figure 5) with varying trends. According to results presents in Figure 5 showing variations among values resulted by ethanolic fraction. Average of Different concentration of $25 \mu \mathrm{l}, 50 \mu \mathrm{l}$ and $75 \mathrm{ul}$ resulted cell viability $0.415583, \quad 0.245493$ and 0.23907 respectively. As we can see from bar graph that alkaloids extracted from $C$. erectus ethanolic concentrations, show some good effect on limiting the proliferation of HepG2 cells in a MTT assay conducted. As our main goal was to find the minimum concentration, which can stop the proliferation of HepG2 cells, third fraction of ethanol $(75 \mu \mathrm{L})$ was very effective against proliferation of

[Citation: Khalil, R., Ali, Q., Hafeez, M.M., Malik, A. (2020). Phenolic acid profiling by RP-HPLC: evaluation of antibacterial and anticancer activities of Conocarpus erectus plant extracts. Biol. Clin. Sci. Res. J., 2020: 10 doi: https://doi.org/10.54112/bcsrj.v2020i1.10]. 
cells. Even a small amount of dose from this fraction cane used to stop the proliferation of cancer cells. This proves the anti-cancer activity of this plant on HepG2 cell line.

AVERAGE OF DOSE, POSITIVE \& NEGATIVE CONTROL WITH S.DEVIATION

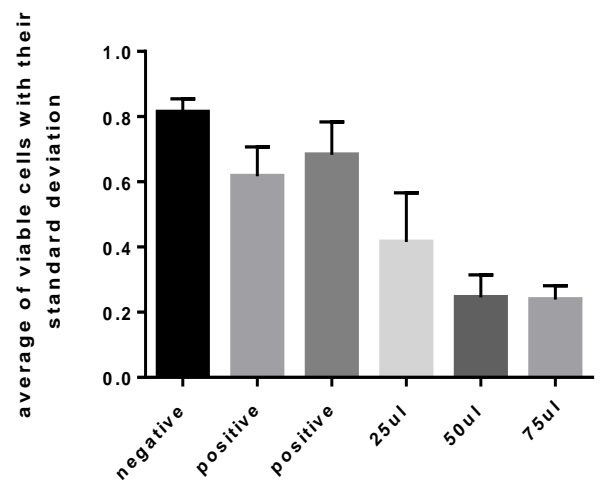

average of all doses

Figure 5. A graph was plotted for all the doses of shoot extract along with negative and positive control to find the average absorbance after MTT assay

\section{Anticancer activity of bark extract on HepG2 cell line}

According to results presents in Figure 6 showing variations among values of \% viability resulted by ethanolic fraction. Average of Different concentration of $25 \mu \mathrm{l}, 50 \mu \mathrm{l}$ and $75 \mathrm{ul}$ resulted cell viability $0.435344,0.222537$ and 0.109633 respectively. Among all different doses, the minimum dose of $25 \mu \mathrm{l}$ showed maximum cell viability i.e. 0.435344 by average while maximum dose of 75 ul showed minimum cell viability i.e. 0.109633 the variation among \% cell viability $10.96 \%$ by dose $75 \mathrm{ul}$ had maximum anticancer activity while fraction of $25 \mathrm{ul}$ had $43.53 \%$ the minimum anticancer property.
A VERAGE OF DOSE, POSITIVE \& NEGATIVE CONTROL WITH S.DEVIATION

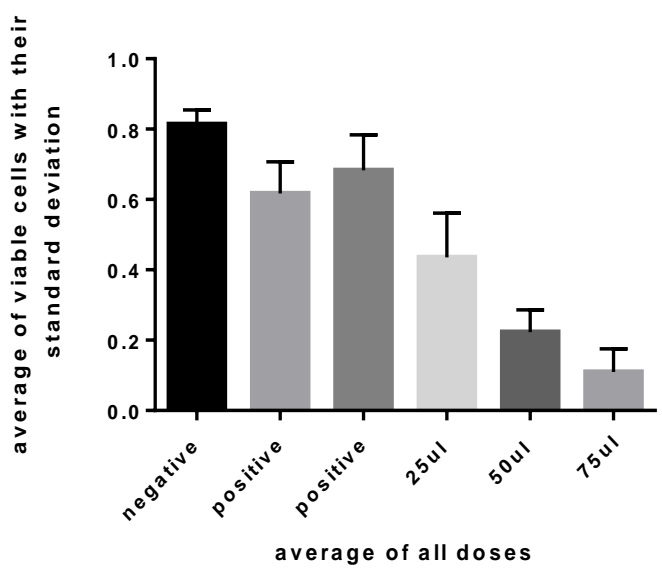

Figure 6. A graph was plotted for all the doses of bark along with negative and positive control to find the average absorbance after MTT assay

\section{Anticancer activity of fruit extract on HepG2 cell line}

According to results presents in Figure 7 showing variations among values of results by ethanolic fraction. Average of Different concentration of $25 \mu \mathrm{l}$, $50 \mu \mathrm{l}$ and $75 \mathrm{ul}$ resulted cell viability 0.641267 , 0.525633 and 0.445043 respectively. As we can see from bar graph that alkaloids extracted from $C$. erectus ethanolic concentrations, show some good effect on limiting the proliferation of HepG2 cells in a MTT assay conducted. As our main goal was to find the minimum concentration, which can stop the proliferation of HepG2 cells, third fraction of ethanol $(75 \mu \mathrm{L})$ was very effective against proliferation of cells. Even a small amount of dose from this fraction cane used to stop the proliferation of cancer cells. This proves the anti-cancer activity of this plant on HepG2 cell line.

[Citation: Khalil, R., Ali, Q., Hafeez, M.M., Malik, A. (2020). Phenolic acid profiling by RP-HPLC: evaluation of antibacterial and anticancer activities of Conocarpus erectus plant extracts. Biol. Clin. Sci. Res. J., 2020: 10 doi: https://doi.org/10.54112/bcsrj.v2020i1.10]. 
A VERAGE OF DOSE, POSITIVE \& NEGATIVE CONTROL WITH S.DEVIATION

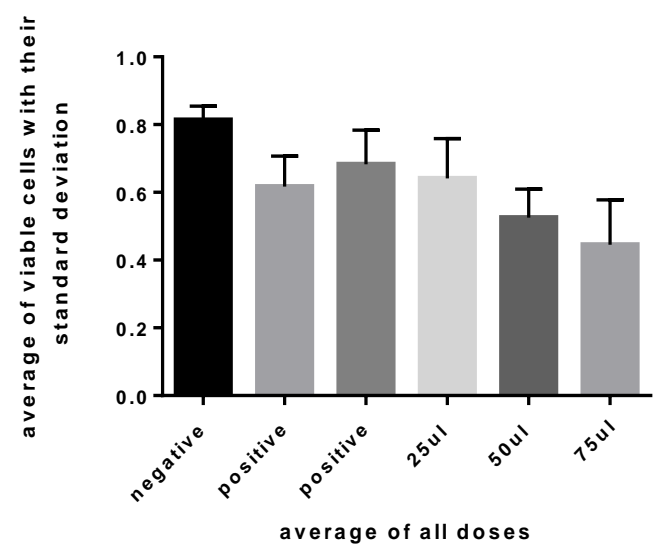

Figure 7. A graph was plotted for all the doses of fruit extract along with negative and positive control to find the average absorbance after MTT assay

Anticancer activity of leaf extract on HepG2 cell line

According to results presents in Figure 8 showing variations among values of $\%$ viability resulted by ethanolic fraction. Average of Different concentration of $25 \mu \mathrm{l}, 50 \mu \mathrm{l}$ and $75 \mathrm{ul}$ resulted cell viability $0.439183, \quad 0.316807$ and 0.204833 respectively. Among all different doses, the minimum dose of $25 \mu \mathrm{l}$ showed maximum cell viability i.e. 0.439183 by average while maximum dose of $75 \mathrm{ul}$ showed minimum cell viability i.e. 0.204833 the variation among \% cell viability $20.48 \%$ by dose $75 \mathrm{ul}$ had maximum anticancer activity while fraction of $25 \mathrm{ul}$ had $43.91 \%$ the minimum anticancer property.

\section{AVERAGE OF DOSE, POSITIVE \& NEGATIVE CONTROL WITH S.DEVIATION}

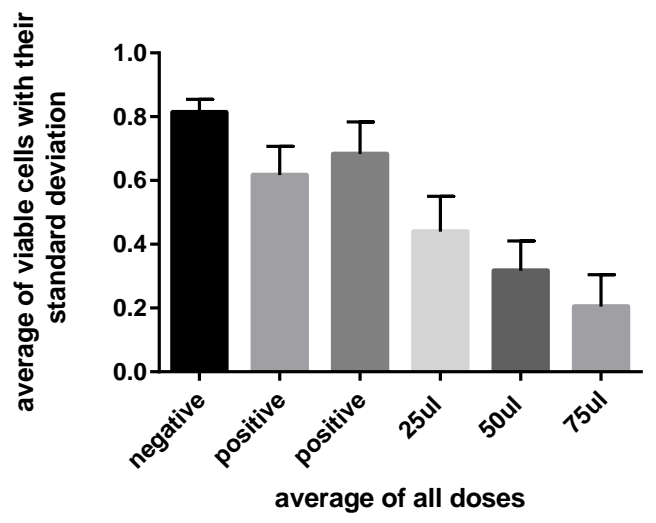

Figure 8. A graph was plotted for all the doses of leaf extract along with negative and positive control to find the average absorbance after MTT assay

HPLC quantification of phenolic acids from Conocarpus erectus fractions

The leaves, bark, fruit and shoot of $C$. erectus has been studied for the phenolic, flavonoid and tannin substances (Figures 9-12). The flavonoid substance were examine by aluminum chloride technique and is correspond in rutin equivalent and the complete tannin and phenolic content were assessed by FolinCiocalteu's reagent (FCR) and expressed in the number of gallic acid equivalent (GAE). In the HPLC examination of ethanol fractions of leaves, bark, shoot and fruit products of $C$. erectus uncovered the nearness of gallic acid, catechin, quercetin, apigenin, quercetin- 3-O-glucoside, kaemferol-3-O-glucoside and rutin. ethanolic extracts of fruits and bark were found to have high phenolic contents equivalent that is $481.1 \pm 8.01$ and $333.9 \pm 5.88 \mathrm{mg} / \mathrm{g} \quad \mathrm{GAE}$ respectively while shoot and leaves have moderate phenolic contents $221.68 \pm 13.34$ and $209.09 \pm 13.34$ $\mathrm{mg} / \mathrm{g}$ GAE respectively. Total flavonoids contents in the ethanolic extract of leaves was found to be $28.0 \pm 1.34 \mathrm{mg} / \mathrm{g}$ RE followed by methanol extracts of fruits $20.3 \pm 0.66$, shoot $13.6 \pm 0.33$ and bark $7.5 \pm 0.83$ $\mathrm{mg} / \mathrm{g} \mathrm{RE}$. In ethanolic extracts of bark and fruits have the highest tannin content equivalent to $149.62 \pm 6.89$ and $141.72 \pm 13.79 \mathrm{mg} / \mathrm{g}$ GAE respectively while ethanol extorts of shoot and leaves have107.54 \pm 7.76 and $76.87 \pm 6.61 \mathrm{mg} / \mathrm{g}$ GAE, respectively. The defatted ethanol extract of fruits of $C$. erectus Ellagic acid, vescalagin, castalagin isomer and di-(hexa hydroxyl diphenoyl) galloyl hexose isomer were uncertainly recognized as main components with many hydrolysable types of tannins. The new trimethoxy-ellagic glycoside was isolated from the leaves of Conocarpus erectus.

[Citation: Khalil, R., Ali, Q., Hafeez, M.M., Malik, A. (2020). Phenolic acid profiling by RP-HPLC: evaluation of antibacterial and anticancer activities of Conocarpus erectus plant extracts. Biol. Clin. Sci. Res. J., 2020: 10 doi: https://doi.org/10.54112/bcsrj.v2020i1.10]. 


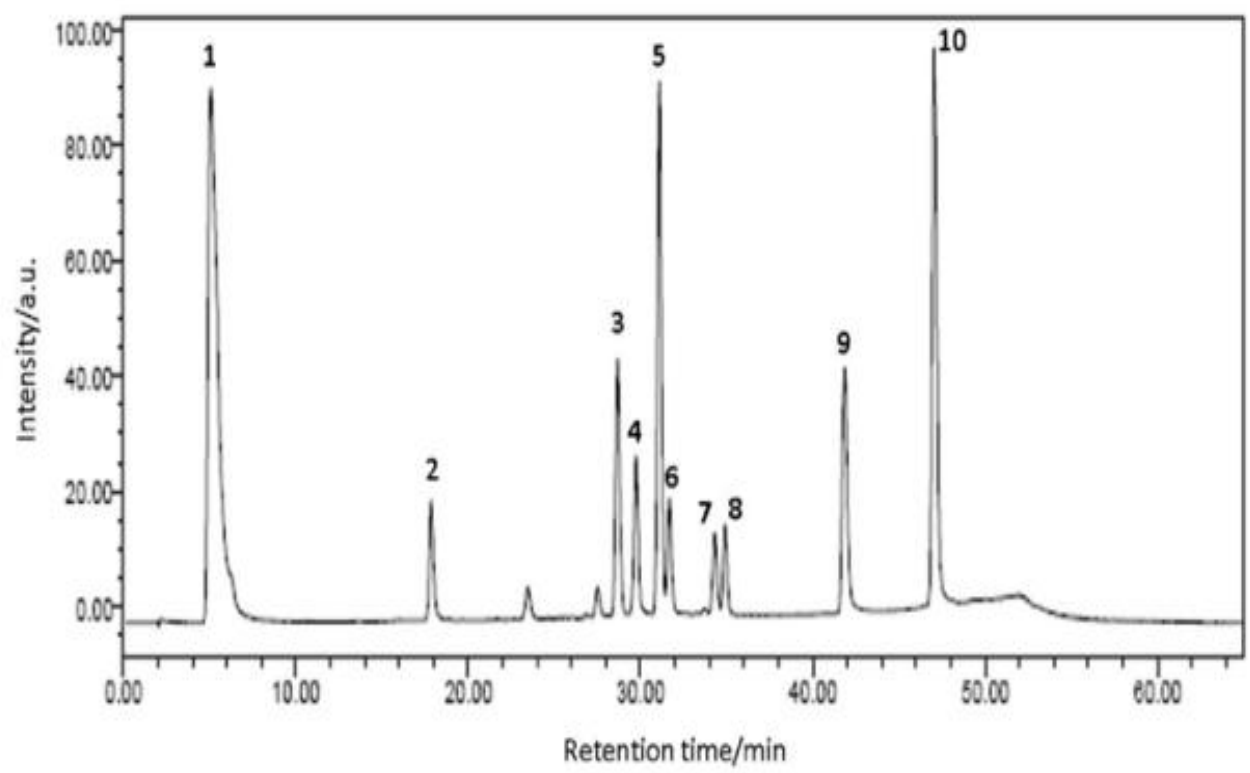

HPLC-UV (280 nm) chromatogram of ten standard phenolic compounds; gallic acid (1), catechin (2), taxifolin (3), quercetin-3-O- $\beta$-D-glucoside-( $1 \rightarrow 6)$-gallic acid (4), rutin (5), quercetin-3-O- $\beta$-D-glucoside (6), kaempferol-3- $O$-rutinoside (7), kaempferol-3- $O$ - $\beta$-D-glucoside (8), quercetin (9) and apigenin (10).

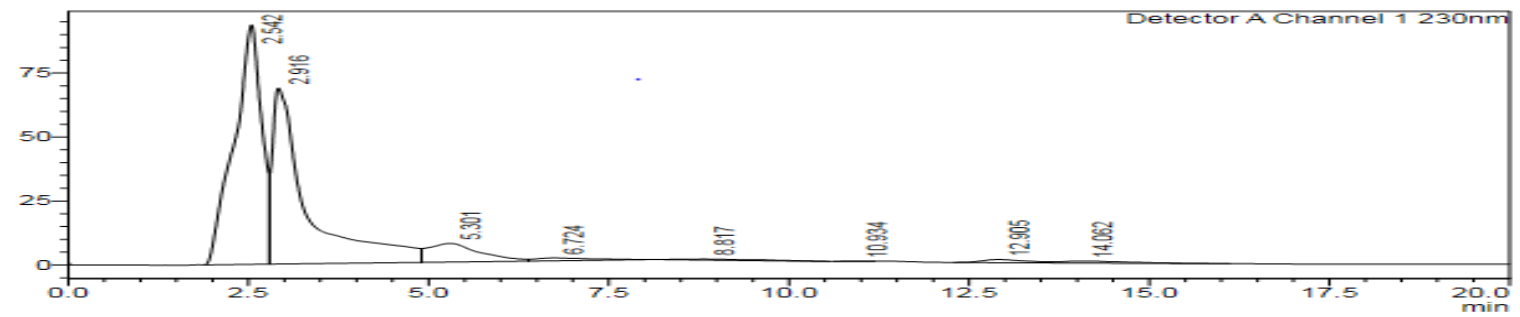

$m \vee$

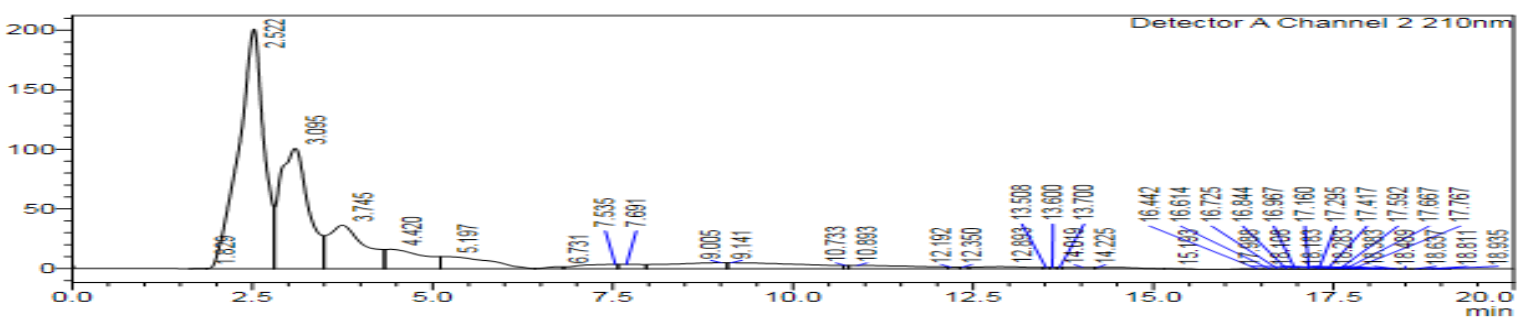

Figure 9. HPLC chromatogram of phenolic acids from alcoholic fraction of $C$. erectus bark

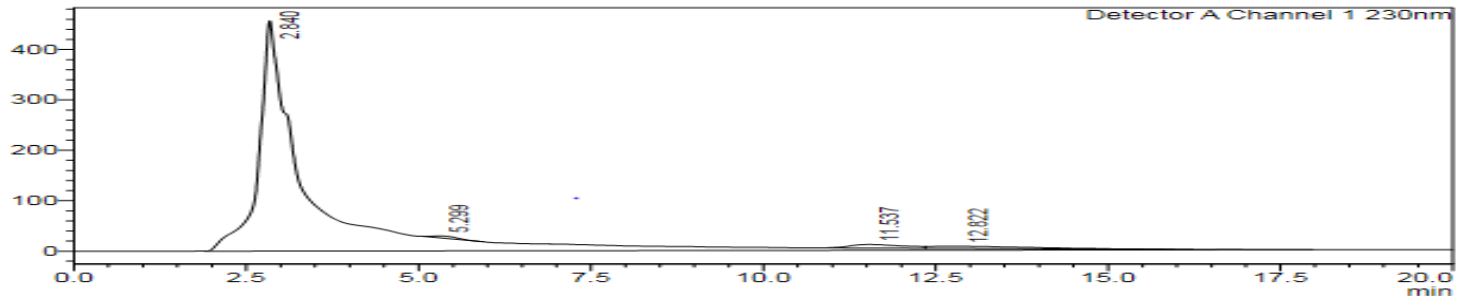

$\mathrm{m} \vee$

$\overline{[\text { Citat }}$

antiba

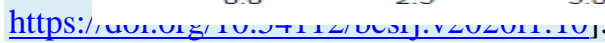

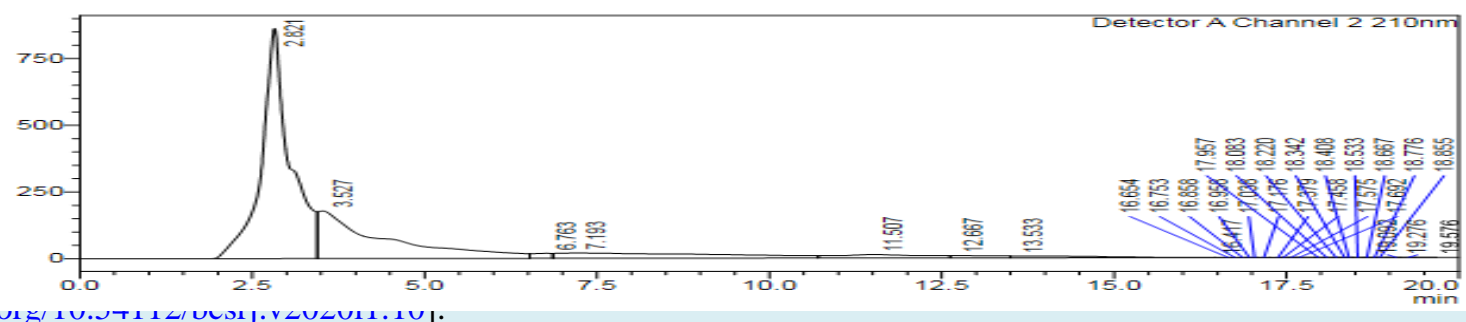


Figure 10. HPLC chromatogram of phenolic acids from alcoholic fraction of $C$. erectus shoot

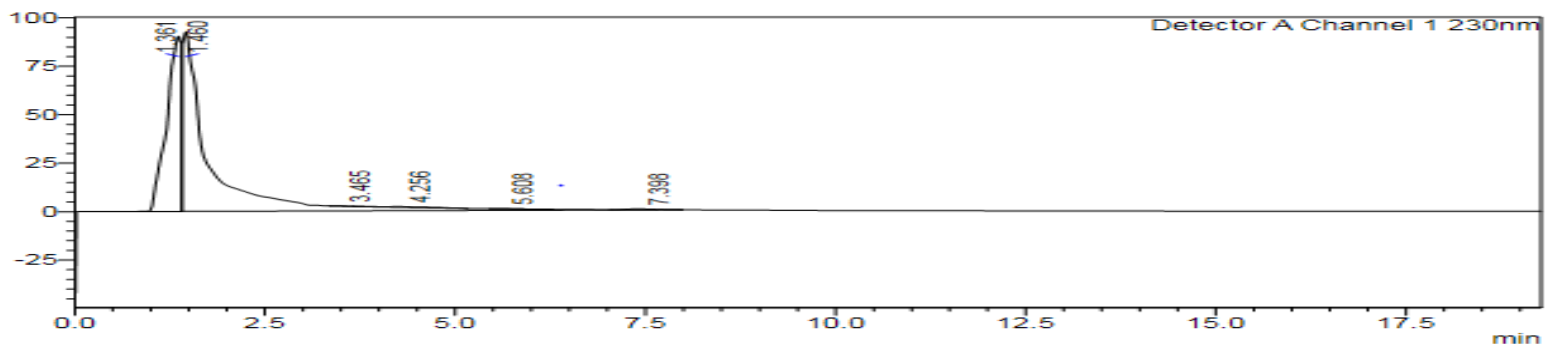

$m \vee$

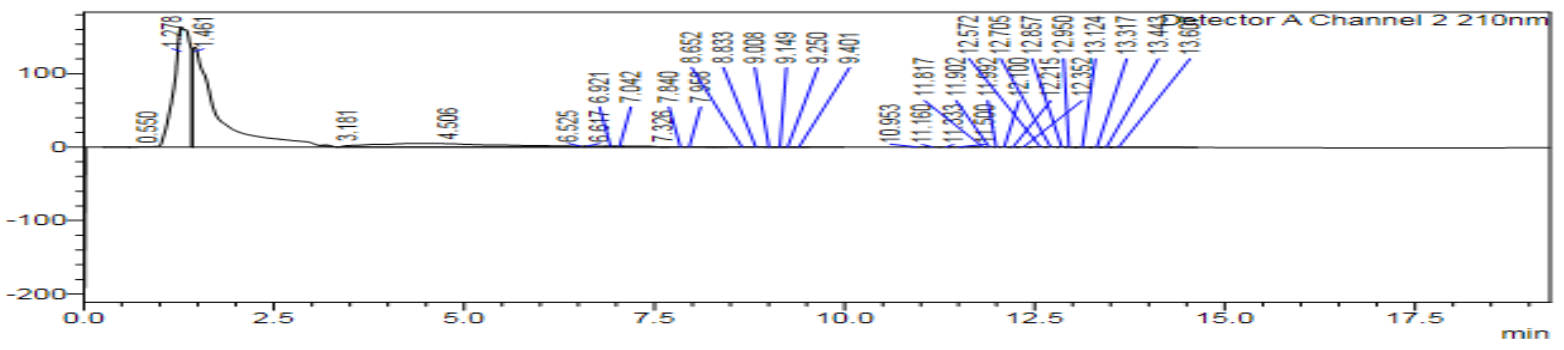

Figure 11. HPLC chromatogram of phenolic acids from alcoholic fraction of $C$. erectus leaves
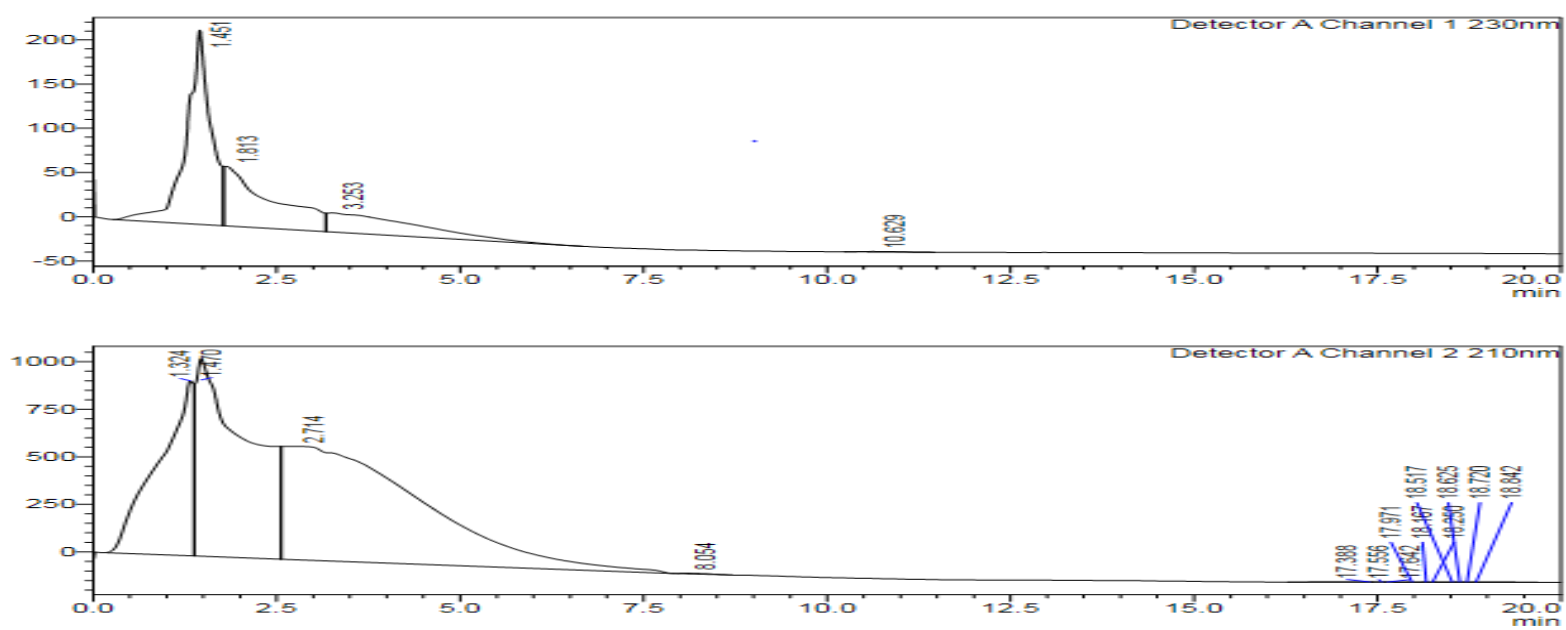

Figure 12. HPLC chromatogram of phenolic acids from alcoholic fraction of $C$. erectus fruit

\section{Discussions}

A bacterial disease is an expansion of destructive strain of microscopic organisms on or inside the body. Microbes can taint any region of the body. Food contamination, Pneumonia and meningitis are only a couple of diseases that might be brought about by dangerous microbes. From the ancient time man has been utilizing plants to fix diverse sicknesses related with pathogenic microorganisms. According to world health organization there are 91 states which use 21000 plants in number as medicine and pharmacopoeias (Khan et al., 2012) examine antibacterial capability of $T$. alexandrinum against gram positive and gram negative medical clinic disconnected human being pathogenic microbes' strains in charge of numerous tropical sicknesses. To assess antibacterial importance of $T$. alexandrinum different extracts of leaves was geared up by using methanol, ethyl acetate, hexane, aqueous extort and DCM solvents. The results showed that methanol and ethyl acetate show higher activity for all strains than other extracts. This concludes that $T$. alexandrinum can be used for the healing of many diseases. Curative properties of therapeutic plants are very much perceived at worldwide facet. Therapeutic plants all the time have been a piece of human society and can possibly fix sundry illnesses caused by microorganisms (Adnan et al., 2014). In Pakistan, because of expanding protection from anti-toxins, scholars are concentrating on antimicrobial exercises of plants against Escherichia coli. Altogether, for invitro against $E$. coli activities extort from 34 ethno medicinally profitable Pakistani plants were

[Citation: Khalil, R., Ali, Q., Hafeez, M.M., Malik, A. (2020). Phenolic acid profiling by RP-HPLC: evaluation of antibacterial and anticancer activities of Conocarpus erectus plant extracts. Biol. Clin. Sci. Res. J., 2020: 10 doi: https://doi.org/10.54112/bcsrj.v2020i1.10]. 
accounted. Methanolic concentrates of therapeutic plants were utilized in distinctive investigations, than n-hexane and fluid concentrates, which have appeared higher inhibitory exercises against E. coli. Plants has been used to improve human health status and for cardiovascular disease and other infections. Conocarpus erectus leaf extract showed that $C$. erectus leaves had antioxidant and antibacterial feature. These discoveries add to logical data for the adequacy on utilization of this plant in the advancement of a phytotherapic compounds, (Santos et al., 2018). In this work to check out the antibacterial activity of Conocarpus erectus parts shoot, bark, fruit and leaves against Gram positive $S$. aureus strain and Gram negative (E. coli, $K$. pneumonia) strains. Gram positive bacteria show more activity than the Gram negative bacteria. Zone of inhibition was recorded by caliper in $\mathrm{cm}$.

Internationally malignant growth is a sickness that seriously affects the human populace. There is a steady interest for new treatments to treat and forestall this hazardous sickness. Logical and examine intrigue is drawing its consideration towards normally inferred mixes as they are considered to have less harmful symptoms contrasted with existing medications, for example, chemotherapy (Greenwell and Rahman, 2015). Prompting the advancement of new clinical medications the Plant Kingdom delivers normally happening optional metabolites that are being researched for their anticancer exercises. New advances are rising to build up the zone further with the achievement of these intensifies that have been formed into staple medications for malignancy treatment. An experiment for the phytochemical and biological activities of different parts (fruit, stem, leaves and flower) of $C$. erectus. The four productive methanolic extort of $C$. erectus parts show high free rummage radical power. Two human cancer lines (hepG2 and MCF-7) were used. The results showed that plant have higher antimicrobial \& anticancer activities and can be used for many therapeutic diseases, (Abdel-Hameed et al., 2012). Cancer is a sickness that is described by cells in the human body constantly increasing with the failure to be controlled or halted. Thus, shaping tumors of dangerous cells with the possibility to be metastatic. Essential oils are found to have different dynamic parts, which can appear in vitro cytotoxic activity against different destructive cell lines (Safwat et al., 2018). An investigation reports the in vitro cytotoxic impacts of the basic oil from Conocarpus erectus. MTT assays and brine shrimp were used to examine the cytotoxic impacts of $C$. erectus. In opposite to brine shrimps larva and HepG2cancer cells Cytotoxicity of the essential oil was deliberate. Methanol extort of $C$. erectus was good against brine shrimp larva, Volatile oil showed good result against human cancer cell line. Graphs show the cytotoxic effects of ethanolic extracts of different parts of the Conocarpus erectus plant against HepG2 cell line by using MTT Assay method (Rahmat et al. 2002). A range of doses prepared by ethanol of three different fractions $(25 \mathrm{ul}$, $50 \mathrm{ul}$ and $75 \mathrm{ul}$ ) of $C$. erectus was used. Potent anticancer activity was resulted by samples of $C$. erectus observed (in graphs) with varying trends. According to results presents in graphs showing variations among values of \% viability resulted by ethanolic fractions. In all the samples bark show the maximum activity with minimum cell viability.

\section{Conclusion}

The focus of this research was to extract the fractions of this plant in ethanol. These fractions were stored and doses were prepared after column chromatography for further analysis of anticancer, antimicrobial and quantification of pheonlic acids using HPLC. For antimicrobial activity, different parts of the plant were used as samples to test its effects on six microbial srains. Graphs were plotted for all strains. For anticancer activity, MTT assay was performed with the four samples obtained in methanol and the triplets of these doses were used on HepG2 cells for this purpose. Graphs were plotted for averages of all samples against negative control and percentages were also calculated. The results are quite promising and showed some good effects against cancer. All the fractions show some promising results. For quantification of phenolic acids from this plant, different parts of the plant were studied which includes: leaves, bark, fruit and shoots. The fractions of these parts were run under HPLC and many acids like: gallic acid, rutin etc. The fractions of ethanol showed the highest amount of phenolic content as compared to other fractions. All this data proves the capability of this plant for as anticancer and antimicrobial activities. In addition, there are a huge number of phenolic compounds are also present in them. Conocarpus erectus has been used for many years now as medicinal plant and have been proved to show anti-cancer and anti-microbial effects. This researched also focused on proving these with fractions obtained in different chemicals and performing anti-cancer activity against HepG2 cell line. The results for all four fractions were satisfying and proved that there are anti-cancer compounds present in it. This was further analyzed using HPLC and found that there are many phenolic

[Citation: Khalil, R., Ali, Q., Hafeez, M.M., Malik, A. (2020). Phenolic acid profiling by RP-HPLC: evaluation of antibacterial and anticancer activities of Conocarpus erectus plant extracts. Biol. Clin. Sci. Res. J., 2020: 10 doi: https://doi.org/10.54112/bcsrj.v2020i1.10]. 
acids which are present in them which further proved is anti-oxidant and anti-cancer properties.

\section{Conflict of interest}

The authors declare absence of any type of conflict of interest.

\section{References}

Abdel-Hameed, E.-S. S., Bazaid, S. A., and Sabra, A. N. A. (2013). Protective effect of conocarpus erectus extracts on CCl4-induced chronic liver injury in mice. Glob J Pharmacol 7, 52-60.

Abdel-Hameed, E.-S. S., Bazaid, S. A., and Shohayeb, M. M. (2014). RP-HPLC-UV-ESI-MS phytochemical analysis of fruits of Conocarpus erectus L. Chemical Papers 68, 1358-1367.

Abdel-Hameed, E.-S. S., Bazaid, S. A., Shohayeb, M. M., El-Sayed, M. M., and El-Wakil, E. A. (2012). Phytochemical studies and evaluation of antioxidant, anticancer and antimicrobial properties of Conocarpus erectus L. growing in Taif, Saudi Arabia. European Journal of Medicinal Plants 2, 93-112.

Adnan, M., Bibi, R., Mussarat, S., Tariq, A., and Shinwari, Z. K. (2014). Ethnomedicinal and phytochemical review of Pakistani medicinal plants used as antibacterial agents against Escherichia coli. Annals of Clinical Microbiology and Antimicrobials 13, 40.

Ayoub, N. A. (2010). A trimethoxyellagic acid glucuronide from Conocarpus erectus leaves: Isolation, characterization and assay of antioxidant capacity. Pharmaceutical biology 48, 328-332.

Bailey, L. (1976). "Hortus Third: A concise dictionary of plant cultivated in US and Canada," Rep. No. 306. Mac'milan publishing Co. Inc.

Bashir, M., Uzair, M., and Chaudhry, B. A. (2015). A review of phytochemical and biological studies on Conocarpus erectus (Combretaceae). Pak J Pharm Res 1, 1-8.

Beutler, J. A. (2009). Natural products as a foundation for drug discovery. Current protocols in pharmacology 46, 9.11. 1-9.11. 21.

Borchardt, J. K. (2002). The Beginnings of Drug Therapy: Ancient Mesopotamian Medicine. Drug news \& perspectives 15, 187-192.

Carneiro, D. B., Barboza, M. S. L., and Menezes, M. P. (2010). Plantas nativas úteis na Vila dos Pescadores da Reserva Extrativista Marinha Caeté-Taperaçu, Pará, Brasil. Acta Botanica Brasilica 24, 1027-1033.

Cragg, G. M., Katz, F., Newman, D. J., and Rosenthal, J. (2012). The impact of the United Nations Convention on Biological Diversity on natural products research. Natural product reports $\mathbf{2 9}$, 1407-1423.

Cragg, G. M., and Newman, D. J. (2013). Natural products: a continuing source of novel drug leads. Biochimica et Biophysica Acta (BBA)General Subjects 1830, 3670-3695.

David, B., Wolfender, J.-L., and Dias, D. A. (2015). The pharmaceutical industry and natural products: historical status and new trends. Phytochemistry Reviews 14, 299-315.

Greenwell, M., and Rahman, P. (2015). Medicinal plants: their use in anticancer treatment. International journal of pharmaceutical sciences and research 6, 4103.

Heinrich, M. (2010). 3.12-Ethnopharmacology and drug discovery. Comprehensive Natural Products II. Elsevier, Oxford 351.

Jagessar, R. C., and Cox, M. (2010). Phytochemical screening of the chcl 3 and ch 3 ch 2 oh extract of stems, twigs, roots and barks of Conocarpus erectus. L. International Journal of Academic Research 2.

Khan, A. V., Ahmed, Q. U., Shukla, I., and Khan, A. A. (2012). Antibacterial activity of leaves extracts of Trifolium alexandrinum Linn. against pathogenic bacteria causing tropical diseases. Asian Pacific journal of tropical biomedicine 2, 189-194.

Kinghorn, A. D., Pan, L., Fletcher, J. N., and Chai, H. (2011). The relevance of higher plants in lead compound discovery programs. Journal of natural products 74, 1539-1555.

Martins, N., Ferreira, I. C., Barros, L., Carvalho, A. M., Henriques, M., and Silva, S. (2015). Plants used in folk medicine: The potential of their hydromethanolic extracts against Candida species. Industrial crops and products 66, 62-67.

Nascimento, D. K., SOUZA, I. A., OLIVEIRA, A. F. D., Barbosa, M. O., Santana, M. A., Pereira Junior, D. F., Lira, E. C., and VIEIRA, J. R. (2016). Phytochemical screening and acute toxicity of aqueous extract of leaves of Conocarpus erectus Linnaeus in Swiss Albino Mice. Anais da Academia Brasileira de Ciências 88, 1431-1437.

Park, E.-J., and Jhon, D.-Y. (2010). The antioxidant, angiotensin converting enzyme inhibition activity, and phenolic compounds of bamboo shoot extracts. LWT-Food Science and Technology 43, 655-659.

Raza, M. A., Anwar, F., Shahwar, D., Majeed, A., Mumtaz, M. W., Danish, M., Nazar, M. F., Perveen, I., and Khan, S. U.-D. (2016).

[Citation: Khalil, R., Ali, Q., Hafeez, M.M., Malik, A. (2020). Phenolic acid profiling by RP-HPLC: evaluation of antibacterial and anticancer activities of Conocarpus erectus plant extracts. Biol. Clin. Sci. Res. J., 2020: 10 doi: https://doi.org/10.54112/bcsrj.v2020i1.10]. 
Antioxidant and antiacetylcholine esterase potential of aerial parts of Conocarpus erectus, Ficus variegata and Ficus maclellandii. Pakistan journal of pharmaceutical sciences 29.

Safwat, G., MM, H., and Helmy, A. (2018). The biological activity of conocarpus erectus extracts and their applications as cytotoxic agents. Homologyonline. 2: 171-184.

Santos, D. K. D. d. N., de Almeida, V. S., de Araujo, D. R. C., Harand, W., Soares, A. K. d. A., Moreira, L. R., de Lorena, V. M. B., Magalhães, L. P. M., Ximenes, R. M., and de Sena, K. X. d. F. R. (2018). Evaluation of cytotoxic, immunomodulatory and antibacterial activities of aqueous extract from leaves of Conocarpus erectus Linnaeus (Combretaceae). Journal of Pharmacy and Pharmacology 70, 1092-1101.

Shohayeb, M., Abdel-Hameed, E., and Bazaid, S. (2013). Antimicrobial activity of tannins and extracts of different parts of Conocarpus erectus L. Int J Pharm Bio Sci 3, 544-553.

von Linsingen, L., Cervi, A. C., and Guimarães, O. (2009). Taxonomic synopsis of the family Combretaceae R. Brown in southern Brazil. Acta Botanica Brasilica 23, 738-750.

West, R. C. (1977). Tidal salt marsh and mangal formations of Middle and South America. In Ecosystems of the World 1, Wet Coastal Ecosystems (Ed. By V.J Chapman), pp. 193-213. Elsevier, Amsterdam. .

\section{(c) (i) (9)}

Open Access This article is licensed under a Creative Commons Attribution 4.0 International License, which permits use, sharing, adaptation, distribution and reproduction in any medium or format, as long as you give appropriate credit to the original author(s) and the source, provide a link to the Creative Commons licence, and indicate if changes were made. The images or other third party material in this article are included in the article's Creative Commons licence, unless indicated otherwise in a credit line to the material. If material is not included in the article's Creative Commons licence and your intended use is not permitted by statutory regulation or exceeds the permitted use, you will need to obtain permission directly from the copyright holder. To view a copy of this licence, visit http://creativecommons.org/licen ses/by/4.0/.

(C) The Author(s) 2021

[Citation: Khalil, R., Ali, Q., Hafeez, M.M., Malik, A. (2020). Phenolic acid profiling by RP-HPLC: evaluation of antibacterial and anticancer activities of Conocarpus erectus plant extracts. Biol. Clin. Sci. Res. J., 2020: 10 doi: https://doi.org/10.54112/bcsrj.v2020i1.10]. 